\title{
Utilization of temporal dominance of sensations and time intensity methodology for development of low-sodium Mozzarella cheese using a mixture of salts
}

\author{
J. F. Rodrigues, ${ }^{1}$ C. S. Gonçalves, R. C. Pereira, J. D. S. Carneiro, and A. C. M. Pinheiro \\ Department of Food Science, Federal University of Lavras, 37200-000, Lavras, MG, Brazil
}

\begin{abstract}
Evidence has linked excessive salt consumption to the development of chronic degenerative diseases. Therefore, special attention has been given to the consumption of healthier products with reduced sodium contents. This study aimed to develop a Mozzarella cheese with a reduced sodium content using a mixture of salts through acceptance testing and temporal sensory evaluation. The following 3 formulations of Mozzarella cheese were prepared: formulation A (control), which was produced only with $\mathrm{NaCl}$ ( $0 \%$ sodium reduction), formulation B (30\% sodium reduction), and formulation C (54\% sodium reduction). Every formulation was produced using a mixture of salts consisting of $\mathrm{NaCl}$, $\mathrm{KCl}$, and monosodium glutamate at different concentrations. The products underwent sensory acceptance tests, and the time intensity and temporal dominance of sensations were evaluated. The proportions of salts used did not cause strange or bad tastes but did result in lower intensities of saltiness. Mozzarella with low sodium content (B and C) had a sensory acceptance similar to that of traditional Mozzarella (A). Therefore, the use of a mixture of salts consisting of $\mathrm{NaCl}, \mathrm{KCl}$, and monosodium glutamate is a viable alternative for the production of Mozzarella, with up to a $54 \%$ reduction in the sodium content while still maintaining acceptable sensory quality.
\end{abstract}

Key words: $\mathrm{KCl}$, monosodium glutamate, temporal dominance of sensations, time intensity

\section{INTRODUCTION}

Sodium chloride is traditionally used as a food additive in food processing. In addition to its influence on the taste of products, it has an important role with regard to texture and storage. However, due to the high sodium content, $\mathrm{NaCl}$ has also been associated with an increased risk of hypertension, the development of

Received January 7, 2014.

Accepted April 16, 2014.

${ }^{1}$ Corresponding author: jessikfr5@hotmail.com cardiovascular disease, osteoporosis, and the incidence of kidney stones (Weinsier, 1976; Sihufe et al., 2003; Heaney, 2006; WHO, 2007). Therefore, special attention has been paid to the consumption of foods containing sodium because of its role in increasing the risk of chronic diseases (Roberfroid, 2000; Menrad, 2003) and, consequently, the emerging need for low-sodium product development (Katsiari et al., 2001; Matthews and Strong, 2005; Ruusunen and Puolanne, 2005; Guàrdia et al., 2008; Albarracín et al., 2011).

Because of concerns about excess sodium intake, the Ministry of Health and the Brazilian food industry reached an agreement to reduce the sodium content of various categories of foods by 2016. The Food Standards Agency in the United Kingdom has also revised its targets for reducing salt $(\mathrm{NaCl})$ in processed foods, and the Food and Drug Administration (FDA) is working with the US food industry to reduce sodium content in foods (FDA, 2010). However, the reduction in sodium content in food products is a challenge for the food industry because it is often reported that a decrease in $\mathrm{NaCl}$ content is associated with a decrease in product acceptance (Sofos, 1983; Breslin and Beauchamp, 1997; Toldrá, 2006).

Several substitutes for $\mathrm{NaCl}$ have been studied. One is $\mathrm{KCl}$ due to its similar physical properties, but complete replacement of $\mathrm{NaCl}$ by $\mathrm{KCl}$ is not recommended because of the bitter taste the latter gives to products, which is generally only somewhat acceptable (Nascimento et al., 2007). Thus, using a combination of salts for the preparation of products with reduced sodium and good sensory acceptance is an interesting option.

In addition to the use of $\mathrm{KCl}$, an interesting alternative to promote the reduction of sodium content in foods is the use of flavor enhancers such as monosodium glutamate (MSG; Brandsma, 2006; Desmond, 2006). The umami taste allows the MSG to be used as a substitute for $\mathrm{NaCl}$, reducing its usage between 30 and $40 \%$ in food (Yamaguchi and Takahashi, 1984). This additive contains approximately $13 \%$ sodium, leading to less than half of the sodium intake of $\mathrm{NaCl}$, where the sodium ion is approximately $40 \%$ of the molecular 
mass. However, when the goal is to reduce the sodium concentration to prevent cardiovascular problems, it cannot be overlooked that MSG, even if at a lower concentration, is also an important source of sodium ( $\mathrm{Su}-$ gita, 2002). Mojet et al. (2004) showed that the umami taste of MSG helps the perception of saltiness in food and predicted that the $\mathrm{NaCl}$ content may be reduced in foods that contain a lot of umami without decreasing consumer acceptance. Therefore, it would be interesting to use a combination of $\mathrm{NaCl}, \mathrm{KCl}$, and $\mathrm{MSG}$ in the production of products with reduced sodium content.

Replacement salts containing $\mathrm{K}, \mathrm{Mg}$, and $\mathrm{Ca}$ have been investigated in various cheeses (Katsiari et al., 2001; Johnson et al., 2009; Ayyash and Shah, 2011a,b; Gomes et al., 2011; Ortakci et al., 2012). Grummer et al. (2012) showed that $\mathrm{KCl}$ can be used successfully to achieve large reductions in sodium when replacing a portion of the $\mathrm{NaCl}$ in Cheddar cheese. It is possible to produce this low-sodium Cheddar cheese in a way that results in high consumer acceptance and low bitterness (Grummer et al., 2013). Another cheese that can be prepared by partial substitution $(25 \%$, wt $/ \mathrm{wt})$ of $\mathrm{NaCl}$ with $\mathrm{KCl}$ at the salting step is low-sodium Minas fresh cheese (Gomes et al., 2011). Kamleh et al. (2012) and Karimi et al. (2012) also demonstrated that Halloumi cheese and Feta cheese could be successfully manufactured using $\mathrm{NaCl}$ and $\mathrm{KCl}$. Kamleh et al. (2012) further suggested using ingredients that would help mask this bitterness and thus improve the acceptability of Halloumi. Drake et al. (2011) studied the sodium reduction in cheese sauce, cottage cheese, and milk-based soup and they found that the complexity of the food matrix influenced salty taste perception and the percentage sodium reduction that was noticeable to consumers. Thus, further research for each product is necessary to further clarify salty taste perception in each product.

Among products with high sodium content, Mozzarella cheese, which, according to research from the National Brazilian Sanitary Surveillance (ANVISA), has an average sodium content of $577 \mathrm{mg} / 100 \mathrm{~g}$, with results ranging from 309 to 1,068 mg (Brazilian Health Surveillance Agency, 2012), stands out. In addition, due to changes in eating habits, including the increased consumption of foods such as fast food and pizza, Mozzarella cheese is currently one of the most manufactured and consumed cheeses in Brazil and in the world (Santos, 2009), In addition, use of Mozzarella cheese as an ingredient in sandwiches and for other culinary applications, has increased, which has resulted in a natural tendency for these products to contain increased sodium contents (Cruz et al., 2011a). Cheeses enhance the taste of preparations to which they are added, including pies, stuffings, and pasta sauces. Recently, high sodium contents of several hot takeout meals in the United Kingdom have been reported, with sodium contents varying from 1.32 to $1.65 \mathrm{~g}$ of salt/100 g across several pizzas, for which the main ingredient is Mozzarella cheese (Jaworowska et al., 2012), which makes reducing the sodium content of this cheese important.

Because the replacement of $\mathrm{NaCl}$ with other salts during the preparation of Mozzarella cheese raises several questions about the potential to reduce the saltiness and the possible introduction of metallic, bitter, and astringent tastes, it is necessary that, in addition to sensory acceptance tests, tests to characterize the sensory profile of the product during its consumption, such as the analysis of time-intensity (TI) and the analysis of temporal dominance of sensations (TDS), are also performed. Therefore, this study aimed to develop an accepted Mozzarella cheese with reduced sodium content, using a mixture of salts consisting of $\mathrm{NaCl}, \mathrm{KCl}$, and MSG in different concentrations, through acceptance testing and temporal sensory evaluation (TI and TDS).

\section{MATERIALS AND METHODS}

\section{Ingredients}

The materials used in the preparation of Mozzarella cheese were standardized and pasteurized milk (3\% fat), mesophilic starter TCC-20, which is a starter culture for direct use that contains Streptococcus salivarius ssp. thermophilus (40\%) and Lactobacillus helveticus (60\%; Chr. Hansen A/S, Hørsholm, Denmark), 50\% (wt/vol) calcium chloride solution, bovine rennet powder (Hansen Industries and Co., Valinhos-SP, Brazil), potassium chloride (99\%; Vetec Química Fina Ltda, Duque de Caxias, RJ, Brazil), MSG (99\%; Ajinomoto, São Paulo, SP, Brazil), and $\mathrm{NaCl}$ (99\%; Vetec Química Fina Ltda).

\section{Preparation of Mozzarella Cheese}

The Mozzarella cheeses were manufactured according to the methodology described by Furtado (1990), with some modifications. Figure 1 shows a flowchart of the manufacturing process for Mozzarella cheese.

For the preparation of Mozzarella formulations, 40 L of homogenized, pasteurized, and standardized milk was tempered to $35 \pm 1^{\circ} \mathrm{C}$ with mesophilic starter in the amount recommended by the manufacturer. Subsequently, the milk was subjected to preaging for a period of $40 \mathrm{~min}$ at the same temperature. After preripening, the milk was added to the $50 \% \mathrm{CaCl}_{2}$ solution $(0.4$ $\mathrm{mL} / \mathrm{L}$ of milk) with rennet powder in an amount sufficient for clotting to occur in $50 \mathrm{~min}$. The obtained curd was cut to obtain $1-\mathrm{cm}^{3}$ edges.

After the cutting step, the solution was allowed to clot at rest for $5 \mathrm{~min}$; then, the curd was slowly stirred for $10 \mathrm{~min}$. To enhance the desired Mozzarella cheese 
Standardized, homogenized and pasteurized milk

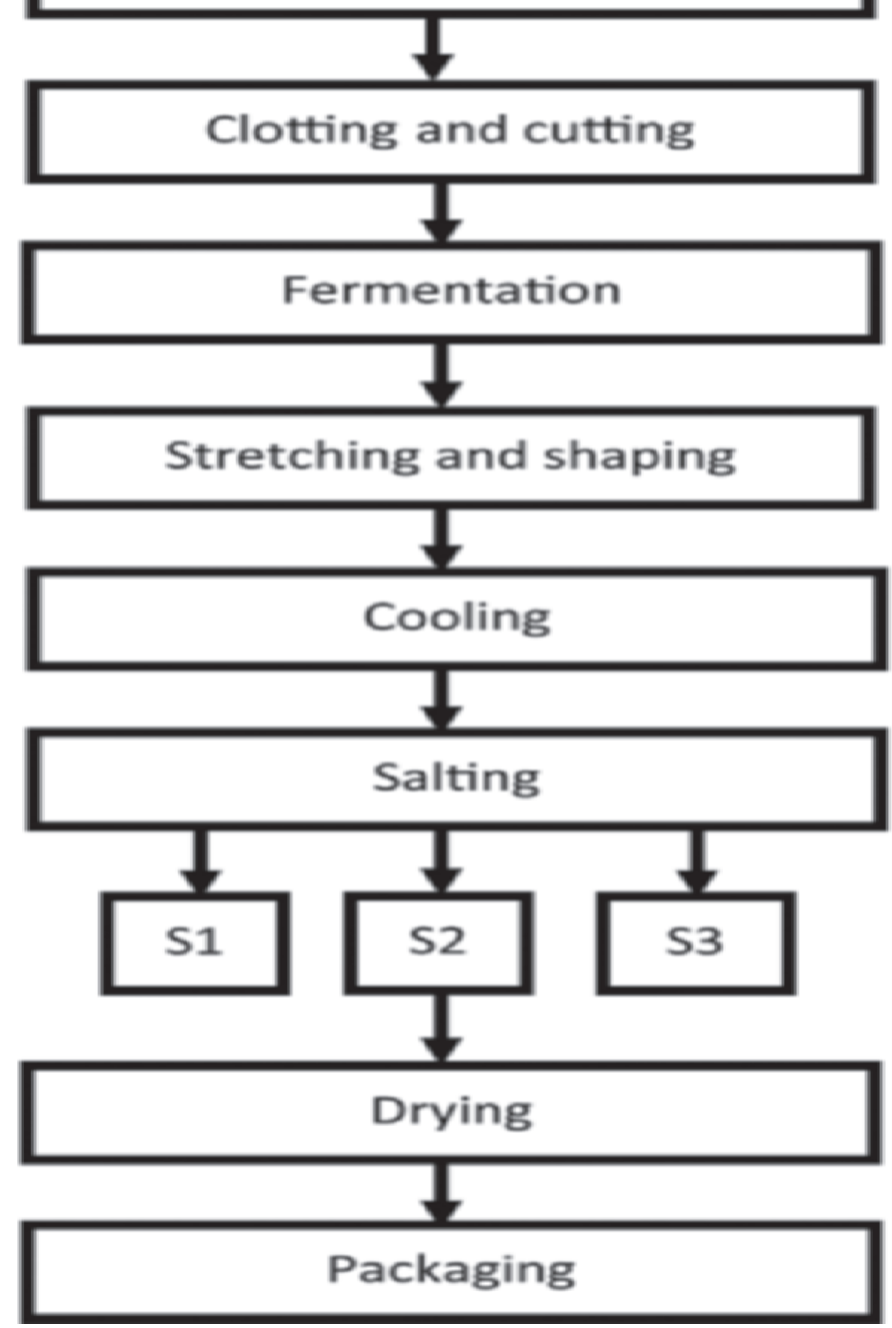

Figure 1. Flowchart of the production of Mozzarella cheese. S1 $=$ traditional brine containing $100 \% \mathrm{NaCl} ; \mathrm{S} 2=$ brine with a $25 \%$ reduction in $\mathrm{NaCl}$ content; $\mathrm{S} 3=$ brine with a $50 \%$ reduction in $\mathrm{NaCl}$ content.

syneresis, the temperature was raised slowly to $40^{\circ} \mathrm{C}$, and the curd was stirred in the tank for an additional 25 min, when it hit the mass point. Upon reaching this point, all the serum was removed, and the mass in the tank was maintained at a temperature of $40^{\circ} \mathrm{C}$ for $1 \mathrm{~h}$ to accelerate the acidification of the dough to achieve a $\mathrm{pH}$ of 5.3. The mass was cut into slices of approximately $1.8 \mathrm{~cm}$ and manually worked into water at $78^{\circ} \mathrm{C}$ for approximately $5 \mathrm{~min}$. The ratio of stretching water:mass used was $2: 1$. The masses were shaped and placed in plastic rectangular forms. The masses were then left to rest for $10 \mathrm{~min}$ (turned after $5 \mathrm{~min}$ ). Afterward, these forms, which contained the Mozzarella cheese, were immersed in water at $8 \pm 1^{\circ} \mathrm{C}$ for $1 \mathrm{~h}$ to promote cooling of the mass to be removed from the forms. Next, the $3 \mathrm{~kg}$ of Mozzarella cheese that was produced was divided into 3 equal parts, and each part was subjected to a different brine (S1, S2, and $\mathrm{S} 3$ ) in a cold chamber at a temperature of $10^{\circ} \mathrm{C}$ for $8 \mathrm{~h}$ to yield the following 3 Mozzarella cheese formulations: (A) traditional Mozzarella cheese salted in brine containing $100 \% \mathrm{NaCl}$ (S1), (B) Mozzarella cheese salted in brine with a $25 \%$ reduction in $\mathrm{NaCl}$ content $(\mathrm{S} 2)$, and (C) Mozzarella cheese salted in brine with a $50 \%$ reduction in $\mathrm{NaCl}$ content (S3).

The composition of the brine (Table 1) was determined using a mixture of salts ( $\mathrm{NaCl}, \mathrm{KCl}$, and $\mathrm{MSG}$ ) at different concentrations while maintaining the same salting power as the brine containing only $\mathrm{NaCl}$ to produce Mozzarella cheese with a 25 to $50 \%$ reduction in sodium content. In doing this, the mixture of salts was determined by pretesting and the salting power of $\mathrm{KCl}$ and glutamate in relation to $\mathrm{NaCl}$ determined by de Souza et al. (2013a) were taken into consideration.

The brine solutions used had a $\mathrm{pH}$ of 5.3 and were used in the ratio of $3 \mathrm{~L}$ of brine per pound of cheese to be salted. After salting, the Mozzarella cheese was removed and dried in the same chamber for $48 \mathrm{~h}$. After this period, the cheeses were packaged in low-density polyethylene bags and subjected to chemical analysis and sensory tests.

\section{Determination of the Sodium Content of Mozzarella Cheese}

To determine the sodium content of the Mozzarella cheese, formulations $\mathrm{A}, \mathrm{B}$, and $\mathrm{C}$ were ground and subjected to digestion with perchloric and nitric acids (AOAC, 1990). The sodium content of the Mozzarella cheese was determined using flame photometry. The results were subjected to ANOVA and a mean comparison (Tukey) test using the statistical program Sisvar (Ferreira, 2002).

Table 1. Composition of brines used for the preparation of Mozzarella cheese formulations

\begin{tabular}{lcccc}
\hline Brine & $\begin{array}{c}\mathrm{NaCl} \\
(\mathrm{kg} / \mathrm{L})\end{array}$ & $\begin{array}{c}\mathrm{KCl} \\
(\mathrm{kg} / \mathrm{L})\end{array}$ & $\begin{array}{c}\text { Monosodium } \\
\text { glutamate }(\mathrm{kg} / \mathrm{L})\end{array}$ & $\begin{array}{c}\text { Reduction in } \\
\text { NaCl content }(\%)\end{array}$ \\
\hline S1 & 0.3000 & - & - & 0 \\
S2 & 0.2250 & 0.0646 & 0.0402 & 25 \\
S3 & 0.1500 & 0.0430 & 0.1608 & 50 \\
\hline
\end{tabular}




\section{Temporal Evaluation of Mozzarella Cheese}

TI Analysis. Time-intensity analysis was performed according to Cadena and Bolini (2011), Morais et al. (2013), and de Souza et al. (2013b). Thirty participants (15 men and 15 women; $24-56$ yr of age) not allergic to dairy, with experience in sensory evaluation, who consumed Mozzarella cheese at least once per week and who had the interest and time availability were selected for the sensory panel analysis of TI through the use of questionnaires. For acquisition and data analysis, the program SensoMaker (Nunes and Pinheiro, 2012) was used. Through a graphical interface in the form of a 10-point scale, with 0 meaning no perception and 10 signifying an extreme perception of salty taste, each tester indicated the intensity of the attribute of the samples with a monadic presentation, using a balanced complete block design (Wakeling and MacFie, 1995) by computer mouse stimulus. In the course of the analysis, messages were presented at the beginning of each step of the analysis with instructions for the action to be performed (Cardello et al., 2003). First, the panelist clicked in the button "start" and took the full amount of the sample during $2 \mathrm{~s}$, after, during $20 \mathrm{~s}$ using the mouse, indicated the intensity of the particular sensory attribute (salty flavor) on the scale. Finishing the analysis, a message indicated the end of the test and the panelist proceeded to another sample.

The software SensoMaker analyzed the data collected during each sensory evaluation session and furnished the following parameters: maximum intensity recorded by the assessor and time in which the maximum intensity was recorded (Palazzo and Bolini, 2009). The data are presented in graphical form (through calculation parameters) using Microsoft Excel 2012 software (Microsoft Corp., Redmond, WA). In the graph, the values represented on the horizontal axis are time, and intensity values are on the vertical axis.

$\boldsymbol{T D S}$. The TDS analysis was performed according Sokolowsky and Fischer (2012), Dinnella et al. (2012), and de Souza et al. (2013a). We recruited 30 participants not allergic to dairy for the TDS analysis. To recruit participants, questionnaires were administered that considered the frequency of consumption of Mozzarella cheese (at least once per week) and experience with sensory analysis. The panelists were trained on the concept of TDS and were introduced to the data acquisition program SensoMaker (Nunes and Pinheiro, 2012). The total duration of the experiment was $20 \mathrm{~s}$, and the attributes selected by the panel, as determined by the conventional method, were salty, bitter, sweet, umami, sour, spicy, astringent, and off-flavor.
After the instructions, the panelists were asked to click in the button "start" and during $2 \mathrm{~s}$ put the sample of Mozzarella cheese (approximately $5 \mathrm{~g}$ ) in their mouth and immediately start the evaluation. During $20 \mathrm{~s}$, using the mouse, the participants were requested to select the dominant taste over that time. They were told that the dominant taste is the taste that is perceived with the greatest clarity and intensity. For each of these 8 descriptors, a button on the computer screen was presented for evaluation.

The presentation of the samples was made in monadic order (Macfie et al., 1989) in disposable white plastic cups coded with 3 -digit numbers. The samples were served one by one, and the assessors were asked to rinse their mouth with water between each sample.

The methodology of Pineau et al. (2009) was used with the SensoMaker software to compute the TDS curves. The curves were plotted $($ smooth $=0.5)$ and used for visual interpretation. In brief, 2 lines were drawn in the TDS graphical display: the "chance level" and the "significance level." The "chance level" is the dominance rate that an attribute can obtain by chance, and the "significance level" is the minimum value that the dominance rate should equal to be considered to be significant (Pineau et al., 2009). The significance level was calculated using the confidence interval of a binomial proportion based on a normal approximation according to Pineau et al. (2009):

$$
P s=P o+1.645 \sqrt{\frac{P o(1-P o)}{n}},
$$

where $P s=$ lowest significant proportion value $(\alpha=$ $0.05)$ at any point in time for the TDS curve, $P_{o}=1 / p$, with $p$ being the number of attributes, and $n=$ number of subjects per replication.

Analogous to the parameters of the TI curves, 3 parameters of the TDS curves for the attribute salty were extracted: namely, maximum dominance rate, duration of the salty dominance, and area under the curve. Duration of the salty dominance and TDS area were calculated only above the "chance level" $(P=1 /$ number of attributes; here, $P=12.5 \%$ ) to exclude interference. Calculation of the dominance rates was conducted using SensoMaker software. For further analyses, the data were exported to Microsoft Excel and the graphs were plotted. The evaluation process according to Pineau et al. (2009) suggested summarizing the data for all evaluations.

For analysis, the results of the curves were considered significant sensations (i.e., above the line "significance level"). Curves were analyzed trough the maximum rate 
of dominance, time of the maximum rate of dominance, and area under the curve.

\section{Sensory Acceptance Evaluation of Mozzarella Cheese}

The Mozzarella cheese formulations (A, B, and C) were analyzed by a sensory test of acceptance. The samples were served in a monadic in 4 sections, and the order of presentation was balanced according to the proposal by Wakeling and MacFie (1995). The test was conducted in individual booths. The panelists received approximately $20 \mathrm{~g}$ of each sample in plastic cups coded with 3-digit numbers at room temperature. The test was performed in cabins with proper lighting and with absence of interferences such as noise and odors (Bowles and Demiate, 2006).

The 60 panelists not allergic to dairy evaluated the samples in terms of the acceptance of salty taste and overall impression of the samples using a 9-point hedonic scale ranging from "extremely dislike" to "extremely like," according to the methodology described by Sidel and Stone (1993).

The results of the acceptance test were subjected to ANOVA using the statistical program SISVAR (Ferreira, 2002). To better visualize the acceptance of the samples, a histogram of the frequency distribution of the values obtained for each sample was also constructed. The histograms make it possible to visualize the segmentation of the hedonic values of each sample, revealing the acceptance level and allowing for the comparison of the performance of 2 or more samples in the study (Behrens et al., 1999).

\section{RESULTS}

\section{Sodium Content of Mozzarella Cheese}

A significant difference $(P \leq 0.05)$ was detected in the sodium content of the different formulations of Mozzarella cheese. Table 2 lists the average sodium content of the Mozzarella cheese formulations (A, B, and $\mathrm{C}$ ). Table 2 shows that the use of the $\mathrm{NaCl}, \mathrm{KCl}$, and MSG salt mixture resulted in cheeses with 30 and $54 \%$ reductions in the sodium content compared with the traditional formulation (A).

\section{TI}

Figure 2 represents the intensity of the salty taste with the passage of time for the Mozzarella cheese formulations analyzed and Table 3 shows the parameters obtained while analyzing the intensity over time for the salty taste of Mozzarella cheese. Figure 2 and Table 3 show that all Mozzarella cheese profiles were similar

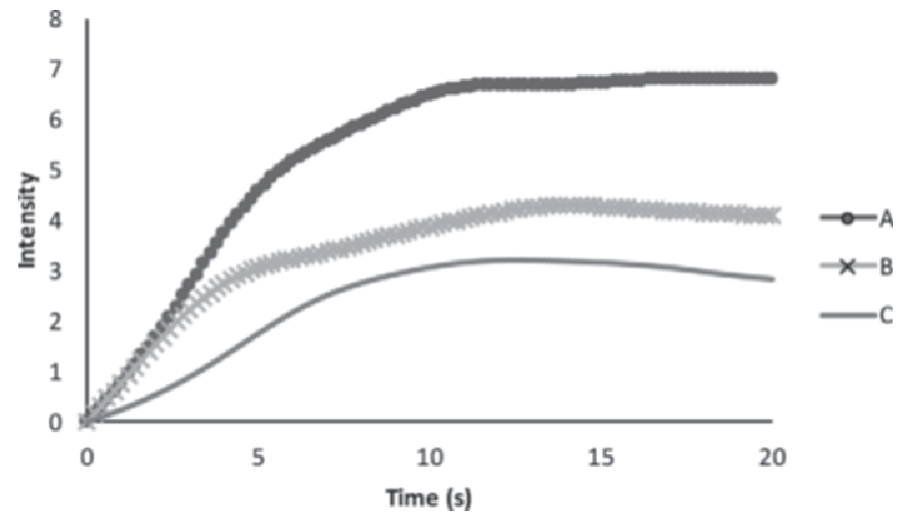

Figure 2. Graphic representation of the intensity of the salty taste with the passage of time for traditional Mozzarella cheese and reduced-sodium Mozzarella cheese. $\mathrm{A}=$ traditional Mozzarella cheese (control); B = Mozzarella cheese with $30 \%$ sodium content reduction; $\mathrm{C}=$ Mozzarella cheese with $54 \%$ sodium content reduction

with respect to the occurrence of the salty taste, but at different intensities. The formulation prepared only with $\mathrm{NaCl}(\mathrm{A})$ showed a maximum intensity of saltiness equal to 6.80 , and it took approximately $18 \mathrm{~s}$ of chewing to achieve this. The Mozzarella cheese with $30 \%$ (B) and $54 \%$ sodium content reduction (C) had a maximum intensity of salty flavor of 4.3 and 3.21 over the course of approximately 14.2 and $12.4 \mathrm{~s}$, respectively.

\section{TDS}

Figures 3, 4, and 5 show the dominant temporal profile of sensations (TDS) of the 3 formulations of Mozzarella cheese studied. Each curve represents a particular attribute of dominance over the course of time. In the graphical representation of the TDS analysis, 2 lines are shown: the "chance level" and "significance level." The "chance level" is the dominance rate that an attribute can obtain by chance, and the "significance level" is the minimum value the dominance rate should equal to be considered significant (Pineau et al., 2009).

Analysis of the TDS for the Mozzarella cheese sample containing only $\mathrm{NaCl}$ (Figure 5) showed that the per-

Table 2. Sodium content in Mozzarella cheese

\begin{tabular}{lcc}
\hline $\begin{array}{l}\text { Mozzarella }_{\text {cheese }^{1}} \\
\text { A }\end{array}$ & $\begin{array}{c}\text { Sodium content } \\
(\mathrm{mg} / 100 \mathrm{~g})\end{array}$ & $\begin{array}{c}\text { Sodium } \\
\text { reduction }\end{array}$ \\
\hline $\mathrm{B}$ & $630 \pm 15.5^{\mathrm{a}}$ & 0 \\
$\mathrm{C}$ & $440 \pm 16.3^{\mathrm{b}}$ & 30 \\
\hline
\end{tabular}

${ }^{a-c}$ Values within a column followed by the same superscript letter are not significantly different from each other $(P<0.05$; by Tukey test).

${ }^{1} \mathrm{~A}=$ traditional Mozzarella cheese (control); $\mathrm{B}=$ Mozzarella cheese with $30 \%$ sodium content reduction; $\mathrm{C}=$ Mozzarella cheese with $54 \%$ sodium content reduction.

${ }^{2}$ Calculated according to formulation $\mathrm{A}$, which was considered $0 \%$ sodium reduction. 
ception of the salty taste was significant at all times. The same is true for sample B, with a $30 \%$ sodium content reduction (Figure 4). As for the Mozzarella cheese with a $54 \%$ sodium content reduction (formulation C), a significant occurrence of salty and umami tastes was present, which occurred over the course of 10 and $12 \mathrm{~s}$, respectively.

The TDS curves also show that formulation A (traditional Mozzarella) reached a maximum salinity dominance rate of approximately 0.65 , meaning that at most $65 \%$ of the panelists selected salinity as the dominant taste), whereas formulations B (30\% sodium content reduction) and C (54\% content sodium reduction) reached a maximum of 0.55 and 0.35 salinity, respectively.

\section{Acceptance Test}

The ANOVA applied to the data for acceptance testing indicated that no significant difference $(P>0.05)$ existed in relation to the acceptance of the attributes of the different formulations of Mozzarella cheese. Table 4 lists the average scores given for acceptance of the salty taste and the overall impression of the Mozzarella cheeses evaluated.

Note that in both attributes, the acceptance grades given to all formulations ranged between "like slightly" and "like moderately," indicating good acceptance of the products. Therefore, a reduction in sodium con-
Table 3. Parameters obtained in the analysis of time-intensity for the Mozzarella cheese formulations

\begin{tabular}{lcc}
\hline Formulation $^{1}$ & $\operatorname{Imax}^{2}$ & $\operatorname{TImax}^{3}$ \\
\hline $\mathrm{A}$ & 6.80 & 18.00 \\
$\mathrm{~B}$ & 4.30 & 14.20 \\
$\mathrm{C}$ & 3.21 & 12.40 \\
\hline
\end{tabular}

${ }^{1} \mathrm{~A}=$ traditional Mozzarella cheese (control); $\mathrm{B}=$ Mozzarella cheese with $30 \%$ sodium content reduction; $\mathrm{C}=$ Mozzarella cheese with $54 \%$ sodium content reduction.

${ }^{2}$ Maximum intensity of saltiness.

${ }^{3}$ Elapsed time to reach the maximum intensity of saltiness.

tent of $30 \%$ (formulation B) and 54\% (formulation C) in Mozzarella cheese promoted the development of products with the same sensory acceptability as the traditional cheese (formulation A). Figures 6 and 7 show histograms obtained from the data for acceptance testing of Mozzarella cheese for a better view of the acceptance of the formulations.

Analysis of the histograms shows slight differences in the frequency distribution of hedonic values assigned to different samples of Mozzarella cheese. In both histograms, the frequency distributions of the responses for all samples skewed toward the region of the highest scores, ranging from "like slightly" (note 6) and "like extremely" (note 9), indicating good acceptance of the products. Formulation C (54\% sodium reduction) had a sensory acceptance slightly superior to that of the other products.

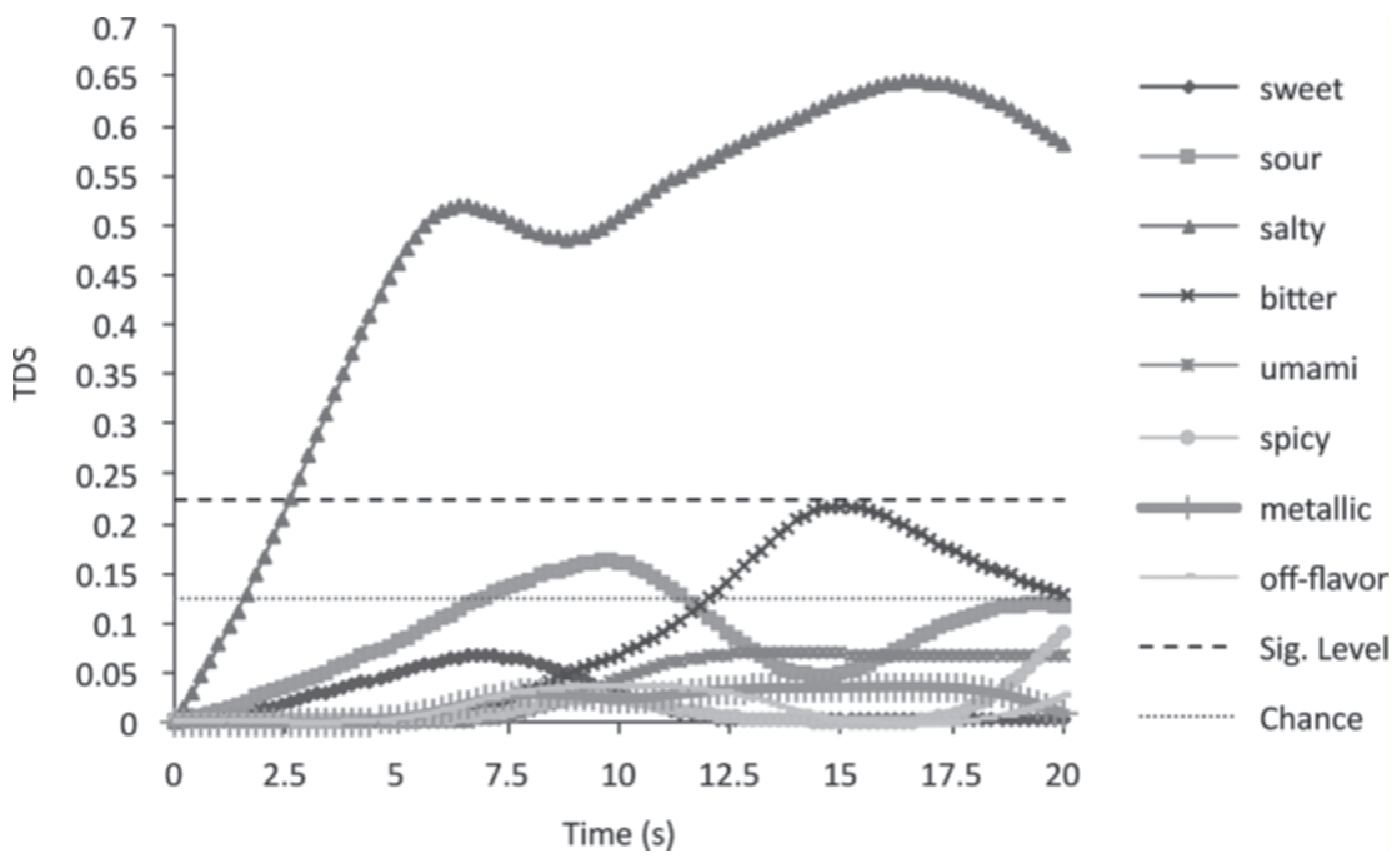

Figure 3. Graphical representation of the temporal dominance of sensations (TDS) profile of traditional Mozzarella cheese. Sig. = significance. 


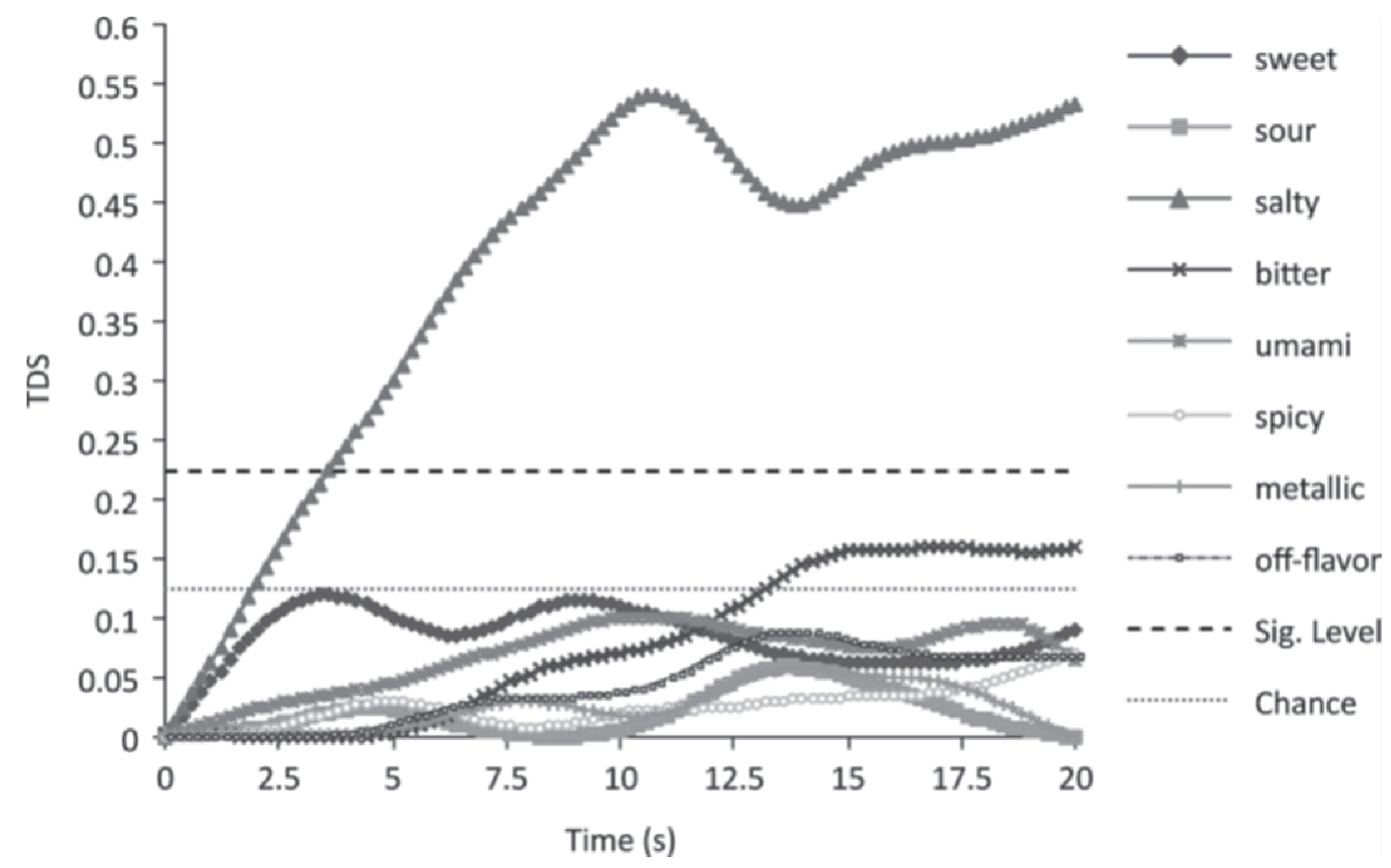

Figure 4. Graphical representation of the temporal dominance of sensations (TDS) profile of Mozzarella cheese with $30 \%$ sodium content reduction. Sig. = significance.

\section{DISCUSSION}

\section{Sodium Content of Mozzarella Cheese}

In a survey of the sodium content of processed foods made by the National Brazilian Sanitary Surveillance (ANVISA) in 2012, it was found that in Brazil, the average content of sodium Mozzarella cheese is 577 mg/100 g (Brazilian Health Surveillance Agency, 2012). Felicio et al. (2013) also found a similar sodium intake for samples of Mozzarella cheese (574.5 mg/100 g). They also found that $75 \%$ of the samples evaluated, according to Brazilian legislation, were classified as high

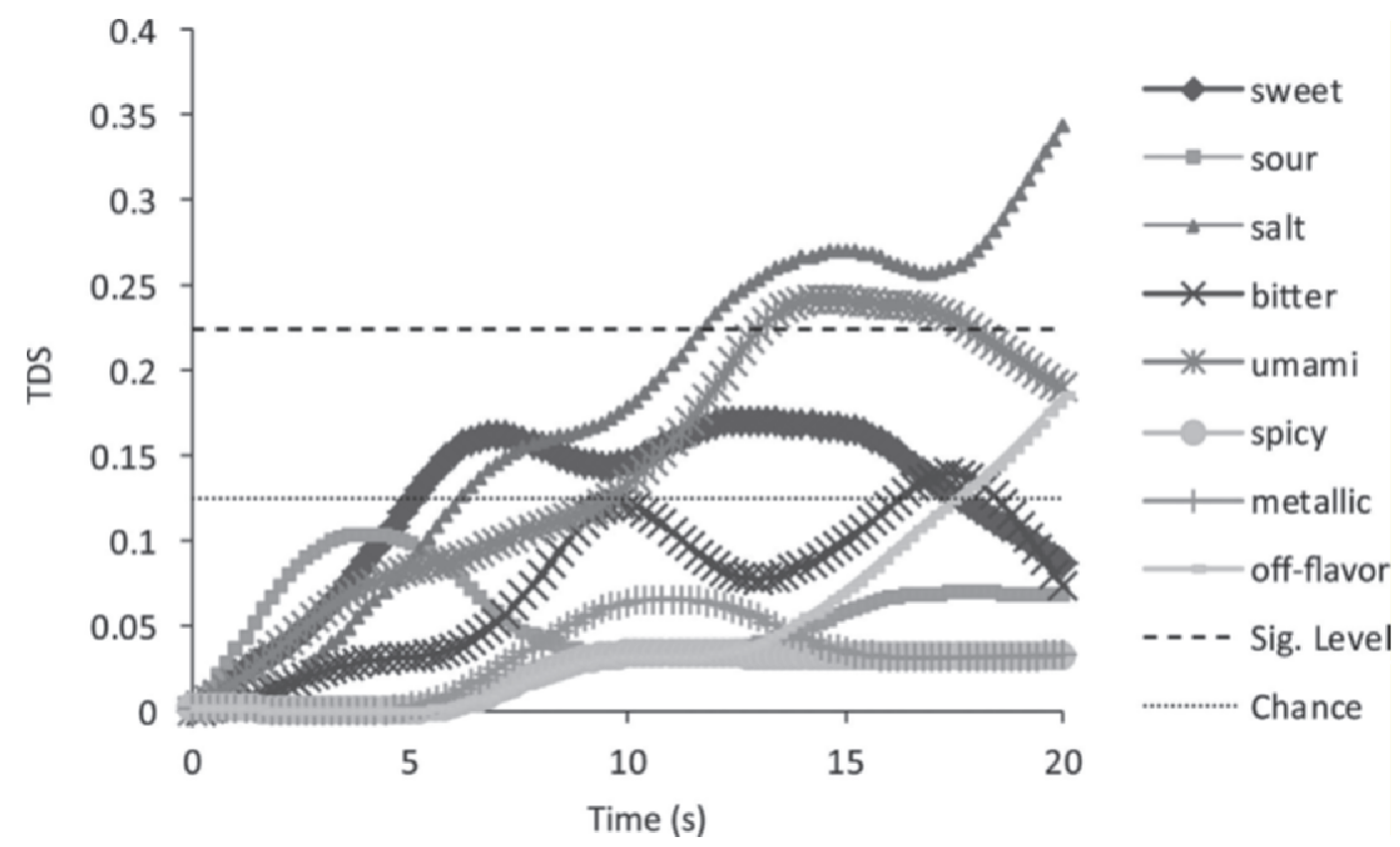

Figure 5. Graphical representation of the temporal dominance of sensations (TDS) profile of Mozzarella cheese with 54\% sodium content reduction. Sig. = significance. 


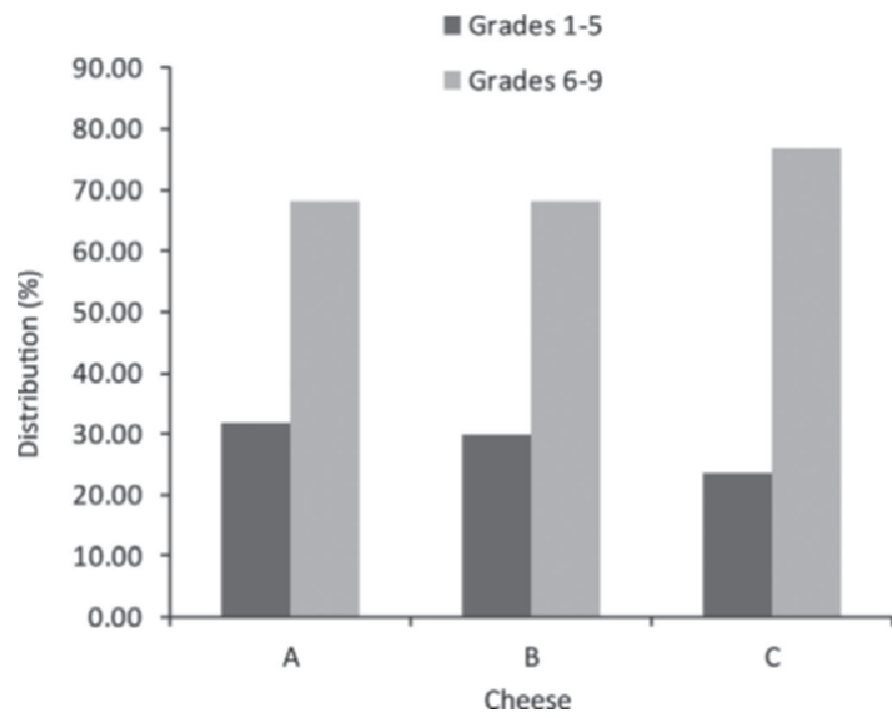

Figure 6. Histogram of frequencies of hedonic values for acceptance in relation to the salty taste of traditional Mozzarella cheese and reduced-sodium Mozzarella cheese. $\mathrm{A}=$ traditional Mozzarella cheese (control); B = Mozzarella cheese with $30 \%$ sodium content reduction; $\mathrm{C}=$ Mozzarella cheese with $54 \%$ sodium content reduction.

sodium. Both showed that different cheese categories presented elevated variability with respect to their sodium contents, suggesting the considerable diversity of processing methods used by manufacturers, which can directly affect the amount of added sodium. Table 2 shows that traditional Mozzarella cheese (formulation A) had an average sodium content of $630 \mathrm{mg} / 100 \mathrm{~g}$,

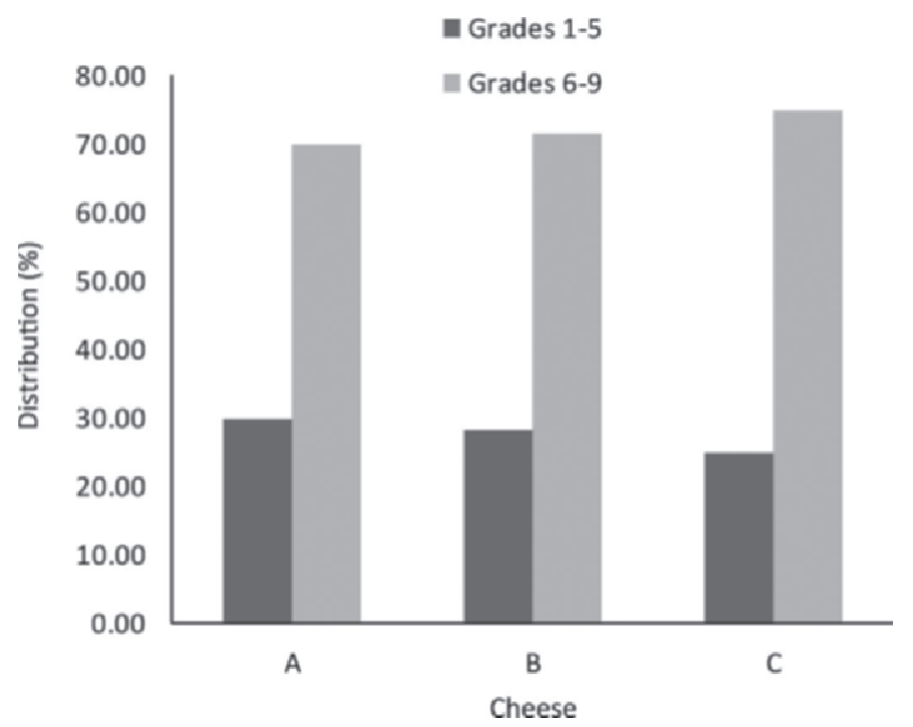

Figure 7. Histogram of frequencies of hedonic values for acceptance in relation to the overall impression of traditional Mozzarella cheese and reduced-sodium Mozzarella cheese. $\mathrm{A}=$ traditional Mozzarella cheese (control); B = Mozzarella cheese with 30\% sodium content reduction; $\mathrm{C}=54 \%$ Mozzarella cheese with sodium content reduction.
Table 4. Acceptance means in relation to the salty taste and overall impression for the formulations of Mozzarella cheese ${ }^{1}$

\begin{tabular}{lcc}
\hline Treatment $^{2}$ & $\begin{array}{c}\text { Salty } \\
\text { taste }\end{array}$ & $\begin{array}{c}\text { Overall } \\
\text { impression }\end{array}$ \\
\hline A & 5.92 & 6.12 \\
B & 6.23 & 6.40 \\
C & 6.43 & 6.48 \\
\hline
\end{tabular}

${ }^{1}$ Sixty panelists not allergic to dairy evaluated the samples in terms of the acceptance of salty taste and overall impression of the samples using a 9-point hedonic scale ranging from "extremely dislike" to "extremely like," according to the methodology described by Sidel and Stone (1993).

${ }^{2} \mathrm{~A}=$ traditional Mozzarella cheese (control); $\mathrm{B}=$ Mozzarella cheese with $30 \%$ sodium content reduction; $\mathrm{C}=$ Mozzarella cheese with $54 \%$ sodium content reduction.

which is above the Brazilian average. However, brining Mozzarella cheeses with 25\% (S2) and 50\% (S3) sodium brine to reduce the $\mathrm{NaCl}$ and $\mathrm{KCl}$ content and using MSG during the preparation of the cheeses (formulations $\mathrm{B}$ and $\mathrm{C}$ ) resulted in products with 30 and $54 \%$ reductions in sodium content, respectively; both samples showed below-average sodium levels (440 and $290 \mathrm{mg} / 100 \mathrm{~g}$, respectively).

A higher percentage of sodium content reduction was found for Mozzarella cheeses B and C in relation to the predicted theoretical reductions of 25 and $50 \% \mathrm{NaCl}$ content, respectively. This greater reduction in sodium levels can be justified due to the difference in the diffusion coefficients of salts in brines. According to Cussler (1976) and Onsager (1945), Fick's laws of diffusion are assumed when various solutes diffuse simultaneously. Thus, besides the diffusion coefficient of each solute in relation to its own concentration gradient, crossed diffusion coefficients are included, representing the influence of a solute on the solute flux of the other solutes (Bona et al., 2005). Typically, the cross terms for highly dissociated solutes, such as $\mathrm{NaCl}$ and $\mathrm{KCl}$, are orders of magnitude lower than the main terms (Medina-Vivanco et al., 2002; Gerla and Rubiolo, 2003).

\section{TI}

The evaluation of the salty taste trough TI analysis is very important in the development of products with reduced sodium content, because the use of other salts to replace $\mathrm{NaCl}$ can promote less perception of the salty taste in the product. By this test, it is possible to find what the best substitutes are for $\mathrm{NaCl}$ and what the best concentrations are of each substitute.

Upon comparing the TI curves (Figure 2), we observed that higher concentrations of $\mathrm{MSG}$ and $\mathrm{KCl}$ were required to achieve the same salty taste sensation as achieved with $\mathrm{NaCl}$. The same was observed by de Souza et al. (2013a) and Teodoro et al. (2013) in their 
experiment with sodium reduction in butter and cream cheese. However, those studies showed that $\mathrm{KCl}$ salt is more similar to $\mathrm{NaCl}$ than MSG. Therefore, according to Guinee and O'Kennedy (2007), the substitution up to $40 \%$ of the $\mathrm{NaCl}$ by $\mathrm{KCl}$ is a good alternative to reduce the sodium content and maintain the characteristic flavor of cheeses. The lower intensity of saltiness in the $\mathrm{C}$ formulation ( $54 \%$ sodium reduction) is likely the result of a higher content of MSG.

Furthermore, the lower perception of salty taste found for samples B (30\% sodium reduction) and C ( $54 \%$ sodium reduction) may be related to the type of cations or anions present in the substance (Ye et al., 1991, 1993) because the salty taste of $\mathrm{NaCl}$ is attributed to both the cations $(70-85 \%)$ and the anions (30-15\%; Formaker and Hill, 1988; Mattes, 2001) and is the result of the passage of ions through an ion channel specific for $\mathrm{NaCl}$ ions (McCaughey, 2007). It is difficult to find other substances with this capability, with the exception of toxic ions. Thus, according to Mooser (1980), other cations, such as potassium, present a less savory flavor compared with $\mathrm{NaCl}$, as observed in this experiment.

Calculations to determine the compositions of brine were performed according to the powers of curing salts found by de Souza et al. (2013a) in butter. Thus, the lower perception of saltiness in Mozzarella cheeses B and $\mathrm{C}$ can also be justified by the different food matrices of the products.

\section{TDS}

Temporal dominance of sensations analysis is also relevant for the development of reduced-sodium-content products, because the use of other salts as substitutes for $\mathrm{NaCl}$ can promote unpleasant tastes, such as metallic, bitter, and astringent (Nascimento et al., 2007; de Souza et al., 2013a; Teodoro et al., 2013;). Furthermore, the temporal analysis TDS and TI allow descriptive evaluating of the products throughout the chewing time.

According to Horita et al. (2011), $\mathrm{KCl}$ is widely used in products with reduced sodium content, but in high concentrations it produces a bitter and metallic taste, resulting in sensory product rejection (Seman et al., 1980; Askar et al., 1994; Armenteros et al., 2012). However, in the current study, Mozzarella cheese containing $\mathrm{KCl}(\mathrm{B}$ and $\mathrm{C}$ ) did not result in the perception of a bitter and metallic taste. This may be due to the combined use of $\mathrm{KCl}$ and MSG because it is postulated that the effect of the flavor enhancer MSG may result from its interaction with taste receptors that minimize the perception of bitter taste (Dutcosky, 2007). Therefore, the use of the combination of these salts as partial sub- stitutes for $\mathrm{NaCl}$ is a good alternative for the production of Mozzarella cheese with reduced sodium content and good consumer acceptance.

In addition to minimizing strange tastes, MSG can be used as a food additive because it is able to confer a distinctive taste to foods recognized as umami, a Japanese expression meaning tasty (Solms, 1969; Kawamura and Kare, 1987). However, its salting power (31.59\%) is well below that of $\mathrm{NaCl}$ (de Souza et al., 2013a). This is consistent with the results found in the TDS curves (Figure 7). Formulation C (54\% sodium reduction), which was prepared with the highest concentration of MSG, exhibited umami and salty flavors, and the salty flavor presented to a lesser extent than in the other samples (A and B). The same taste was noticeable in the studies by de Souza et al. (2013a) and Teodoro et al. (2013) with butter and cream cheese.

Sensory characteristics, functional properties, and shelf life are the features most affected by the reduction of salt in food (Guinee and O'Kennedy, 2007). Thus, in the development of products with reduced sodium content, it is important to consider the nature and composition of the product, the type of treatment, and the manufacturing conditions (Ruusunen and Puolanne, 2005). Although many salt substitutes are on the market, according to Cruz et al. (2011a), $\mathrm{NaCl}$ is the only salt that promotes the manifestation of a pure salty taste. However, this experiment showed that it is possible to prepare Mozzarella cheese with $30 \%$ less sodium using a mixture of $\mathrm{NaCl}$ and $\mathrm{KCl}$ salts and MSG that has a salty taste similar to that made with $\mathrm{NaCl}$ (Figure 4).

\section{Acceptance Test}

Several recent studies have developed products with reduced sodium content and good acceptability, but in all cases, partial substitution of $\mathrm{NaCl}$ was used, and the $\mathrm{NaCl}$ was replaced with different mixtures of salts (Katsiari et al., 2001; Guinee and O'Kennedy, 2007; Cruz et al., 2011a; Horita et al., 2011; Ayyash et al., 2013). In the current study, the use of a mixture of $\mathrm{NaCl}, \mathrm{KCl}$, and MSG was a good alternative for the preparation of products with reduced sodium content. This combination enabled the preparation of Mozzarella cheese with up to $54 \%$ reduction in sodium (formulation C), which maintained good acceptability and similar acceptance relative to the salty taste and the overall impression of the traditional Mozzarella cheese.

Except in products intended for children less than 1 yr old, requiring further studies, MSG is considered a safe additive in concentrations commonly used and its use is governed by leading regulatory agencies (Carvalho et al., 2011). However, it is important to highlight 
that MSG contains $13 \%$ sodium. Therefore, it cannot be used in large proportions when the objective is to reduce the sodium content of the product. In the case of the production of Mozzarella cheese, as the salts, including MSG, were added to the brine and had different diffusion coefficients, MSG could be added in larger quantities without contributing significantly to the sodium content of the final cheese. Therefore, the replacement of $\mathrm{NaCl}$ by MSG is a good alternative to reduce the sodium content in cheeses salted in brine.

Results obtained in acceptance testing show that the consumers did not require a high intensity of salty taste in Mozzarella cheese, being able to accept and appreciate a product with a lower intensity of salt. Møller et al. (2013) showed the same during the production of Cheddar cheese with a $50 \%$ reduction in salt content. Thus, another alternative to promote the reduction of sodium content in Mozzarella cheese is the simple reduction of $\mathrm{NaCl}$ content used during its preparation. This is possible, as consumers have been increasingly concerned with the concept of well-being (Ares et al., 2014) and human health risk factors. Consequently, they have sought healthier products with lower salt content (Drake et al., 2011).

According to Grimes et al. (2009), few studies have examined the consumer's ability to interpret nutrition information regarding salt labels on food products. Consistently across studies, consumers criticize the use of the scientific terminology "sodium" on nutrition food labels (Grunert and Wills, 2007). Thus, according to Petersen et al. (2013), it is necessary to educate the consumers to read food labels to choose low-sodium products. Similarly, salt awareness campaigns are needed (Kenten et al., 2013) and strategies to reduce salt intake must raise interest in engaging in salt reduction through improving understanding of intake levels and dietary sources of salt. Strategies have been suggested by Mendoza et al. (2014).

For better characterization of Mozzarella cheese, future studies should cover sensory profiling of sodiumreduced Mozzarella cheese using quantitative descriptive analysis and consumer profiling methodologies (Albenzio et al., 2013; Cadena et al., 2013; Cruz et al., 2013; Pimentel et al., 2013; Sant'Ana et al., 2013; Santos et al., 2013; Morais et al., 2014).

\section{CONCLUSIONS}

It is possible to produce Mozzarella cheese with up to a $54 \%$ reduction in sodium content and good acceptability using the following mixture of salts: $42.40 \%$ $\mathrm{NaCl}, 12.15 \% \mathrm{KCl}$, and $45.45 \% \mathrm{MSG}$, although the products have lower intensities of saltiness and umami taste manifestation. Temporal dominance of sensations and TI analysis are important tools in the development of products with reduced sodium content. Through this analysis, it was possible to describe the sensorial profile of the products and to optimize the formulations. For better characterization of the new product reduced-sodium Mozzarella cheese, future studies using descriptive sensorial analysis and physical and chemical analysis should be done. Furthermore, as $\mathrm{NaCl}$ has an important role in cheese conservation, the cheese shelf life should be investigated. This work paves the way for future studies, supporting the development of new products with reduced sodium content, taking into account the desires and needs of consumers.

\section{ACKNOWLEDGMENTS}

We thank the postgraduate program in food science from the Federal University of Lavras (Lavras, MG, Brazil), funders, and companies who supplied salt replacer and Mozzarella cheese-making ingredients. The financial support by Fundação de Amparo a Pesquisa de Minas Gerais (FAPEMIG, Sâo Pedro, MG, Brazil) is gratefully acknowledged. The use of trade names in this publication does not imply endorsement by the funding organization, the University of Lavras, or the researchers, nor does it imply criticism of materials we did not evaluate.

\section{REFERENCES}

Albarracín, W., I. C. Sánchez, R. Grau, and J. M. Barat. 2011. Salt in food processing; usage and reduction: A review. Int. J. Food Sci. Technol. 46:1329-1336.

Albenzio, M., A. Santillo, M. Caroprese, A. Braghieri, A. Sevi, and F. Napolitano. 2013. Composition and sensory profiling of probiotic Scamorza ewe milk cheese. J. Dairy Sci. 96:2792-2800. http:// dx.doi.org/10.3168/jds.2012-6273.

AOAC (Association of Official Analytical Chemists). 1990. Official Methods of Analysis. 15th ed. AOAC, Washington, DC.

Ares, G., L. De Saldamando, A. Giménez, and R. Deliza. 2014. Food and wellbeing. Towards a consumer-based approach. Appetite 74:61-69.

Armenteros, M., M.-C. Aristoy, J. M. Barat, and F. Toldrá. 2012 Biochemical and sensory changes in dry-cured ham salted with partial replacements of $\mathrm{NaCl}$ by other chloride salts. Meat Sci. 90:361-367.

Askar, A., S. K. El-Samahy, and M. Tawfik. 1994. Pasterna and beef bouillon. The effect of substituting $\mathrm{KCl}$ and $\mathrm{K}$-lactate for sodium chloride. Fleischwirtschaft 73:289-292.

Ayyash, M. M., and N. P. Shah. 2011a. The effect of substitution of $\mathrm{NaCl}$ with $\mathrm{KCl}$ on chemical composition and functional properties of low-moisture Mozzarella cheese. J. Dairy Sci. 94:3761-3768.

Ayyash, M. M., and N. P. Shah. 2011b. Proteolysis of low-moisture Mozzarella cheese as affected by substitution of $\mathrm{NaCl}$ with $\mathrm{KCl}$. J. Dairy Sci. 94:3769-3777.

Ayyash, M. M., F. Sherkat, and N. P. Shah. 2013. Effect of partial $\mathrm{NaCl}$ substitution with $\mathrm{KCl}$ on the texture profile, microstructure, and sensory properties of low-moisture Mozzarella cheese. J. Dairy Res. 80:7-13. http://dx.doi.org/10.1017/S002202991200043X.

Behrens, J. H., M. A. A. P. Da Silva, and I. N. Wakeling. 1999. Affective sensory tests and internal analysis of preference in acceptability assessment of Brazilian varietal white wines. Ciênc. Tecnol. Aliment. 19. http://dx.doi.org/10.1590/S0101-20611999000200011. 
Bona, E., D. Borsato, R. S. S. F. Silva, and L. H. M. Silva. 2005. Multicomponent diffusion during simultaneous brining of Prato Brazilian cheese. Ciênc. Tecnol. Aliment. 25:394-400.

Bowles, S., and I. M. Demiate. 2006. Physicochemical characterization of the soymilk byproduct Okara. Ciênc. Tecnol. Aliment. 26:652-659.

Brandsma, I. 2006. Reducing sodium. A European perspective attitudes and regulations regarding sodium in foods pose challenges for the food industry. Ciênc. Tecnol. Aliment. 60:24-29.

Brazilian Health Surveillance Agency. 2012. Sodium processed foods. Technical Report no. 50/2012 Sodium processed foods. Brazilian Health Surveillance Agency, Brasília, Brazil.

Breslin, P. A. S., and G. K. Beauchamp. 1997. Salt enhances flavour by suppressing bitterness. Nature 387:563.

Cadena, R. S., and H. M. A. Bolini. 2011. Time-intensity analysis and acceptance test for traditional and light vanilla ice cream. Food Res. Int. 44:677-683.

Cadena, R. S., A. G. Cruz, R. R. Netto, W. F. Castro, J. A. F. Faria, and H. M. A. Bolini. 2013. Sensory profile and physicochemical characteristics of mango nectar sweetened with high intensity sweeteners throughout storage time. Food Res. Int. 54:1670-1679.

Cardello, H. M. A. B., M. A. P. Silva, and M. H. Damásio. 2003. System data collection time-intensity. Boletim da Sociedade Brasileira de Ciência e Technologia de Alimentos 37:54-60.

Carvalho, P. R. R. M., V. J. Bolognesi, S. M. W. Barreira, and C. E. R. Garcia. 2011. Characteristics and safety of monosodium glutamate as food additive: Article review. Visão Acadêmica 12:53-64.

Cruz, A. G., A. E. C. Antunes, R. M. S. Celeghini, and J. A. Faria. 2011a. Processed cheese: Relevance for low sodium cheese development. Pages 1-14 in Cheese: Types, Nutrition and Consumption. R. D. Foster, ed. Nova Science Pub. Inc., New York, NY.

Cruz, A. G., R. S. Cadena, W. F. Castro, E. A. Esmerino, J. B. Rodrigues, L. Gaze, J. A. F. Faria, M. Q. Freitas, R. Deliza, and H. M. A. Bolini. 2013. Consumer perception of probiotic yogurt: Performance of check all that apply (CATA), projective mapping, sorting and intensity scale. Food Res. Int. 54:601-610.

Cruz, A. G., J. A. F. Faria, M. A. R. Pollonio, H. M. A. Bolini, R. M. S. Celeghini, D. Granato, and N. Shah. 2011b. Cheeses with reduced sodium content: Effects on functionality, public health benefits and sensory properties. Trends Food Sci. Technol. 22:276-291.

Cussler, E. L. 1976. Multicomponent Diffusion. E. L. Cussler, ed. Elsevier, Amsterdam, the Netherlands.

Desmond, E. 2006. Reducing salt: A challenge for the meat industry. Meat Sci. 74:188-196.

de Souza, V. R., T. V. Marques Freire, C. S. Gonçalves, J. D. S. Carneiro, A. C. M. Pinheiro, and C. A. Nunes. 2013a. Salt equivalence and temporal dominance of sensations of different sodium chloride substitutes in butter. J. Dairy Res. 80:319-325. http://dx.doi. org/10.1017/S0022029913000204.

de Souza, V. R., P. A. P. Pereira, A. C. M. Pinheiro, H. M. A. Bolini, S. V. Borges, and F. Queiroz. 2013b. Analysis of various sweeteners in low-sugar mixed fruit jam: Equivalent sweetness, timeintensity analysis and acceptance test. Int. J. Food Sci. Technol. 48:1541-1548.

Dinnella, C., C. Masi, G. Zoboli, and E. Monteleone. 2012. Sensory functionality of extra-virgin olive oil in vegetable foods assessed by temporal dominance of sensations and descriptive analysis. Food Qual. Prefer. 26:141-150.

Drake, S. L., K. Lopetcharat, and M. A. Drake. 2011. Salty taste in dairy foods: Can we reduce the salt? J. Dairy Sci. 94:636-645. http://dx.doi.org/10.3168/jds.2010-3509.

Dutcosky, S. D. 2007. Sensory Analysis of Food. S. D. Dutcosky, ed. Editora Universitária Champagnat, Curitiba, Brazil.

FDA (Food and Drug Administration). 2010. FDA news release. FDA issues statement on IOM sodium report. Accessed Oct. 23, 2013. http:// www.fda.gov/NewsEvents/Newsroom/PressAnnouncements/ucm 209155.htm.

Felicio, T. L., E. A. Esmerino, A. G. Cruz, L. C. Nogueira, R. S. L. Raices, R. Deliza, H. M. A. Bolini, and M. A. R. Pollonio. 2013. Cheese. What is its contribution to the sodium intake of Brazilians? Appetite 66:84-88.
Ferreira, D.F. 2002. SISVAR - Systems analysis of variance for balanced data: Statistical analysis and program planning experiments. Version 4.3. Universidade Federal de Lavras (UFLA), Lavras, MG, Brazil.

Formaker, B. K., and D. L. Hill. 1988. An analysis of residual $\mathrm{NaCl}$ taste response after amiloride. Am. J. Physiol. 255:R1002-R1007.

Furtado, M. M. 1990. Art and Science of Cheese. M. M. Furtado, ed. Editora Globo S/A, São Paulo, Brazil.

Gerla, P. E., and A. C. Rubiolo. 2003. A model for determination of multicomponent diffusion coefficients in foods. J. Food Eng. $56: 401-410$.

Gomes, A. P., A. G. Cruz, R. S. Cadena, R. M. S. Celeghini, J. A. F. Faria, H. M. A. Bolini, M. A. R. Pollonio, and D. Granato. 2011. Manufacture of low-sodium Minas fresh cheese: Effect of the partial replacement of sodium chloride with potassium chloride. J. Dairy Sci. 94:2701-2706.

Grimes, C. A., L. J. Riddell, and C. A. Nowson. 2009. Consumer knowledge and attitudes to salt intake and labelled salt information. Appetite 53:189-194.

Grummer, J., N. Bobowski, M. Karalus, Z. Vickers, and T. C. Schoenfuss. 2013. Use of potassium chloride and flavor enhancers in low sodium Cheddar cheese. J. Dairy Sci. 96:1401-1418. http:// dx.doi.org/10.3168/jds.2012-6057.

Grummer, J., M. Karalus, K. Zhang, Z. Vickers, and T. C. Schoenfuss. 2012. Manufacture of reduced-sodium Cheddar-style cheese with mineral salt replacers. J. Dairy Sci. 95:2830-2839. http://dx.doi. org/10.3168/jds.2011-4851.

Grunert, K. G., and J. M. Wills. 2007. A review of European research on consumer response to nutrition information on food labels. J. Public Health 15:385-389.

Guàrdia, M. D., L. Guerrero, J. Gelabert, P. Gou, and J. Arnau. 2008. Sensory characterisation and consumer acceptability of small calibre fermented sausages with $50 \%$ substitution of $\mathrm{NaCl}$ by mixtures of $\mathrm{KCl}$ and potassium lactate. Meat Sci. 80:1225-1230.

Guinee, T. P., and B. T. O'Kennedy. 2007. Mechanisms of taste perception and physiological controls. Pages $246-287$ in Reducing Salt in Foods: Practical Strategies. T. P. Guinee and B. T. O'Kennedy, ed. CRC Press, Boca Raton, FL.

Heaney, R. P. 2006. Role of dietary sodium in osteoporosis. J. Am. Coll. Nutr. 25:271S-276S.

Horita, C. N., M. A. Morgano, R. M. S. Celeghini, and M. A. R. Pollonio. 2011. Physico-chemical and sensory properties of reduced-fat mortadella prepared with blends of calcium, magnesium and potassium chloride as partial substitutes for sodium chloride. Meat Sci. 89:426-433.

Jaworowska, A., T. Blackham, L. Stevenson, and I. G. Davies. 2012. Determination of salt content in hot takeaway meals in the United Kingdom. Appetite 59:517-522.

Johnson, M. E., R. Kapoor, D. J. McMahon, D. R. McCoy, and R. G. Narasimmon. 2009. Reduction of sodium and fat levels in natural and processed cheeses: Scientific and technological aspects. Comp. Rev. Food Sci. Food Safety 8:252-268.

Kamleh, R., A. Olabi, I. Toufeili, N. E. O. Najm, T. Younis, and R. Ajib. 2012. The effect of substitution of sodium chloride with potassium chloride on the physicochemical, microbiological, and sensory properties of Halloumi cheese. J. Dairy Sci. 95:1140-1151. http://dx.doi.org/10.3168/jds.2011-4878.

Karimi, R., A. M. Mortazavian, and M. Karami. 2012. Incorporation of Lactobacillus casei in Iranian ultrafiltered Feta cheese made by partial replacement of $\mathrm{NaCl}$ with KCl. J. Dairy Sci. 95:42094222. http://dx.doi.org/10.3168/jds.2011-4872.

Katsiari, M. C., E. Alichanidis, L. P. Voutsinas, and I. G. Roussis. 2001. Proteolysis in reduced sodium Kefalograviera cheese made by partial replacement of $\mathrm{NaCl}$ with $\mathrm{KCl}$. Food Chem. 73:31-43.

Kawamura, Y., and M. R. Kare, editors 1987. Umami: A Basic Taste: Physiology, Biochemistry, Nutrition, Food Science. Marcel Dekker, New York, NY.

Kenten, C., A. Boulay, and G. Rowe. 2013. Salt. UK consumers' perceptions and consumption patterns. Appetite 70:104-111. 
MacFie, H. J., N. Bratchell, K. Greenhoff, and L. Vallis. 1989. Designs to balance the effect of order of presentation and first-order carryover effects in hall tests. J. Sens. Stud. 4:129-148.

Mattes, R. D. 2001. The taste of fat elevates postprandial triacylglycerol. Physiol. Behav. 74:343-348.

Matthews, K., and M. Strong. 2005. Salt-Its role in meat products and the industry's action plan to reduce it. Nutr. Bull. 30:55-61.

McCaughey, S. 2007. Dietary salt and flavor: Mechanisms of taste perception and physiological controls. Pages 77-98 in Reducing Salt in Foods: Practical Strategies. D. Kilcast and F. Angus, ed. CRC Press, Boca Raton, FL.

Medina-Vivanco, M., P. J. do A. Sobral, and M. D. Hubinger. 2002. Osmotic dehydration of tilapia fillets in limited volume of ternary solutions. Chem. Eng. J. 86:199-205.

Mendoza, J. E., G. A. Schram, J. Arcand, S. Henson, and M. L'Abbe. 2014. Assessment of consumers' level of engagement in following recommendations for lowering sodium intake. Appetite 73:51-57.

Menrad, K. 2003. Market and marketing of functional food in Europe. J. Food Eng. 56:181-188.

Mojet, J., J. Heidema, and E. Christ-Hazelhof. 2004. Effect of concentration on taste-taste interactions in foods for elderly and young subjects. Chem. Senses 29:671-681.

Møller, K. K., F. P. Rattray, W. L. P. Bredie, E. Høier, and Y. Ardö. 2013. Physicochemical and sensory characterization of Cheddar cheese with variable $\mathrm{NaCl}$ levels and equal moisture content. J. Dairy Sci. 96:1953-1971.

Mooser, G. 1980. Membrane transitions in taste receptor cell activation by sodium salts. Pages 275-287 in Biological and Behavioral Aspects of Salt Intake. M. R. Kare, M. J. Fregly, and R. A. Bernard, ed. Academic Press Inc., New York, NY.

Morais, E. C., A. G. Cruz, and H. M. A. Bolini. 2013. Gluten-free bread: Multiple time-intensity analysis, physical characterisation and acceptance test. Int. J. Food Sci. Technol. 48:2176-2184.

Morais, E. C., A. G. Cruz, J. A. F. Faria, and H. M. A. Bolini. 2014 Prebiotic gluten-free bread: Sensory profiling and drivers of liking. Lebensm. Wiss. Technol. 1:248-254.

Nascimento, R. D., P. C. B. Campagnol, E. S. Monteiro, and M. A. R. Pollonio. 2007. Replacement of sodium chloride by potassium chloride: Influence on the physicochemical and sensory characteristics of sausages. Alimentos e Nutrição 18:297-302.

Nunes, C. A., and A. C. M. Pinheiro. 2012. SensoMaker. Version 1.0. Universidade Federal de Lavras UFLA, Lavras, MG, Brazil.

Onsager, L. 1945. Theories and problems of liquid diffusion. Ann. N. Y. Acad. Sci. 46:241-265.

Ortakci, F. J. R. Broadbent, W. R. McManus, and D. J. McMahon. 2012. Survival of microencapsulated probiotic Lactobacillus paracasei LBC-1e during manufacture of Mozzarella cheese and simulated gastric digestion. J. Dairy Sci. 95:6274-6281.

Palazzo, A. B., and H. M. A. Bolini. 2009. Multiple time-intensity analysis and acceptance of raspberry-flavored gelatin. J. Sens. Stud. 24:648-663.

Petersen, K. S., D. J. Torpy, I. M. Chapman, M. Guha, P. M. Clifton, K. Turner, and J. B. Keogh. 2013. Food label education does not reduce sodium intake in people with type 2 diabetes mellitus. A randomised controlled trial. Appetite 68:147-151.

Pimentel, T. C., A. G. Cruz, and S. H. Prudencio. 2013. Short communication: Influence of long-chain inulin and Lactobacillus paracasei subspecies paracasei on the sensory profile and acceptance of a traditional yogurt. J. Dairy Sci. 96:6233-6241. http://dx.doi. org/10.3168/jds.2013-6695.

Pineau, N., P. Schlich, S. Cordelle, C. Mathonnière, S. Issanchou, A. Imbert, M. Rogeaux, P. Etiévant, and E. Köster. 2009. Temporal dominance of sensations: Construction of the TDS curves and comparison with time-intensity. Food Qual. Prefer. 20:450-455.

Roberfroid, M. B. 2000. Concepts and strategy of functional food science: The European perspective. Am. J. Clin. Nutr. 71:1660S$1664 \mathrm{~S}$.
Ruusunen, M., and E. Puolanne. 2005. Reducing sodium intake from meat products. Meat Sci. 70:531-541.

Sant'Ana, A. M. S., F. F. Bezerril, M. S. Madruga, A. S. M. Batista, M. Magnani, E. L. Souza, and R. C. R. E. Queiroga. 2013. Nutritional and sensory characteristics of Minas fresh cheese made with goat milk, cow milk, or a mixture of both. J. Dairy Sci. 96:7442-7453.

Santos, B. A., M. A. R. Pollonio, A. G. Cruz, V. C. Messias, R. A. Monteiro, T. L. C. Oliveira, J. A. F. Faria, M. Q. Freitas, and H. M. A. Bolini. 2013. Ultra-flash profile and projective mapping for describing sensory attributes of prebiotic mortadellas. Food Res. Int. 54:1705-1711.

Santos, M. V. 2009. Milk with high SCC has a lower yield for the manufacture of Mozzarella cheese. Accessed Dec. 13, 2013. http://www. milkpoint.com.br/radar-tecnico/qualidade-do-leite/leite-com-ccselevada-tem-menor-rendimento-para-fabricacao-de-queijomussarela-35209n.aspx.

Seman, D. L., D. G. Olson, and R. W. Mandigo. 1980. Effect of reduction and partial replacement of sodium on bologna characteristics and acceptability. J. Food Sci. 45:1116-1121.

Sidel, J. L., and H. Stone. 1993. The role of sensory evaluation in the food industry. Food Qual. Prefer. 4:65-73.

Sihufe, G. A., S. E. Zorrilla, and A. C. Rubiolo. 2003. Casein degradation of Fynbo cheese salted with $\mathrm{NaCl} / \mathrm{KCl}$ brine and ripened at various temperatures. J. Food Sci. 68:117-123.

Sofos, J. N. 1983. Effects of reduced salt $(\mathrm{NaCl})$ levels on sensory and instrumental evaluation of Frankfurters. J. Food Sci. 48:16921696

Sokolowsky, M., and U. Fischer. 2012. Evaluation of bitterness in white wine applying descriptive analysis, time-intensity analysis, and temporal dominance of sensations analysis. Anal. Chim. Acta 732:46-52.

Solms, J. 1969. The taste of amino acids, peptides, and proteins. J. Agric. Food Chem. 17:686-688.

Sugita, Y. 2002. Flavor enhancers. Pages 409-445 in Food Additives. 2nd ed. Revised and expanded. A. L. Branen, P. M. Davidson, S. Salminen, and J. H. Thorngate III, ed. Marcel Dekker, New York, NY.

Teodoro, S. T. L., V. R. De Souza, C. A. Nunes, and A. C. M. Pinheiro. 2013. Equivalence salting and temporal dominance of sensations analysis for different sodium chloride substitutes in cream cheese. Int. J. Dairy Technol. 67:31-38.

Toldrá, F. 2006. Dry-cured ham. Pages 164-1-164-11 in Handbook of Food Science, Technology, and Engineering. Vol. 4. Y. H. Hui, E. Castell-Perez, L. M. Cunha, I. Guerrero-Legarreta, H. H. Liang, Y. M. Lo, D. L. Marshall, W. K. Nip, F. Shahidi, F. Sherkat, R. J. Winger, and K. L. Yam, ed. CRC Press, Boca Raton, FL.

Wakeling, I. N., and H. J. H. MacFie. 1995. Designing consumer trials balanced for first and higher orders of carry-over effect when only a subset of $k$ samples from $t$ may be tested. Food Qual. Prefer. 6:299-308

Weinsier, R. L. 1976. Overview: Salt and the development of essential hypertension. Prev. Med. 5:7-14.

WHO (World Health Organization). 2007. Prevention of cardiovascular disease: Guidelines for assessment and management of cardiovascular risk. Accessed Oct. 26, 2013. http://whqlibdoc.who.int/ publications $/ 2007 / 9789241547178 \_$_eng.pdf?ua $=1$.

Yamaguchi, S., and C. Takahashi. 1984. Interactions of monosodium glutamate and sodium chloride on saltiness and palatability of a clear soup. J. Food Sci. 49:82-85.

Ye, Q., G. L. Heck, and J. A. DeSimone. 1991. The anion paradox in sodium taste reception: Resolution by voltage-clamp studies. Science 254:724-726.

Ye, Q., G. L. Heck, and J. A. DeSimone. 1993. Voltage dependence of the rat chorda tympani response to $\mathrm{Na}^{+}$salts: Implications for the functional organization of taste receptor cells. J. Neurophysiol. $70: 167-178$ 